\title{
Characterization of transmissivity in the fractured reservoirs in the Oumé area (Centre of Côte d'Ivoire)
}

\author{
Derving Baka ${ }^{1}$, Théophile Lasm ${ }^{\star^{1}}$, Marie-Solange Oga ${ }^{1}$, Marc Youan TA ${ }^{1,2}$, Omer De \\ Lasme $^{1}$, Suzane Ourapa Kouakou ${ }^{1}$, Franck Boni Ettien ${ }^{1}$
}

${ }^{1}$ Laboratory of Sciences and Techniques of Water and Environment Engineering, Unit of formation and Research of Earth Sciences and Mining Resource (UFR-STRM), University of Cocody, 22 B.P. 582 Abidjan 22 (Côte d'Ivoire), telephone : +225 22483 802/ 803 ;

Fax : + 22522445270

${ }^{2}$ University Research Center of Remote Sensing and Application (CURAT), University of Cocody, 22 BP 801 Abidjan 22 (Côte d'Ivoire), Telephone and Fax : +: 22522445270.

\begin{abstract}
The aims of this work were a better knowledge of hydraulic properties of fractured reservoirs in the Oumé area and to estimate the transmissivity of highly fractured hard rock using geostatistical approaches. The boreholes available tapping the fractured reservoirs and have a total depth oscillate between 39 to $93 \mathrm{~m}$. The inflows are met between 1 to $63 \mathrm{~m}$ from the top of crystalline basement. Aquifers of crystalline rocks are more productive that those in the schists. Geostatistical approach is used to perform an assessment of transmissivity on Oumé area. The variographic analysis of $\log T$ showed a spatial structuring with a small nugget effect witch represented $17 \%$ of the total dispersion. Cross-validation results showed that conditions of unbiasedness and optimality are met. The actual and estimated transmissivity values spread respectively on four and two orders of magnitude. This result was explained by missing of data and the kriging smoothing. Actual transmissivity values and kriging estimated values were comparables in statistical viewpoint. Estimated transmissivity values can be accepted and transmissivity map obtained will be used for the aquifer modelling. Geostatistical approach used in this study has supplied satisfactory results in the knowledge of this important parameter on the Oumé area.
\end{abstract}

Keywords: Productivity, fractured aquifer, transmissivity, kriging, Côte d'Ivoire

\section{INTRODUCTION}

The rapid development of the Oumé area and the result increase in the population estimate to $3.8 \%$ per year brought about a drastic increase in water requirements, which might be in the long term become problematic.

Better knowledge and management of water resources are necessary. Since several decades many studies have been achieved on this domain and many models have been proposed.

Water supply for drinking of the populations makes jointly surface water and groundwater in Africa in generally and in Côte d'Ivoire principally and representing 70 and $30 \%$ respectively. In Côte d'Ivoire, essential of groundwaters resources is localised in fractured reservoirs of the crystalline basement, which occupies $97.5 \%$ of land area (Lasm, 2000 ; Lasm et al., 2004). In the crystalline basement zone and in tropical region, two types of reservoirs was distinguished (Biémi, 1992, Faillat, 1986 ; Lasm, 2000) : weathered and fractured reservoirs. These two types of reservoirs are often superimposed or arranged laterally (Faillat, 1986). Weathered and fractured aquifers have respectively a capacitive and a conductive function. Fractured reservoirs are often more quantitative than weathered reservoirs. Besides, they possess many advantages than weathered reservoirs. Because of their depth, these fractured reservoirs are often safe from all seasonal fluctuation and pollutions hazards. Thus, fractured aquifers are protected by weathered material and their resources are healthy from the bacteriological and parasitological threats (Collin, 1988).

The knowledge of the fracturing in the Oumé is very fragmentary, indeed, very few studies have been achieved (Géomines, 1982; Faillat, 1986 ; Soro, 2010). For having better knowledge of the fractured reservoirs, this study has been carried out. This 
present study concerns a zone localized in the Centre of Côte d'Ivoire where the available boreholes for water supply for drinking are numerous. During last two decades, several research drilling programmes have been carried out in the Oumé area, to improve the supply of drinking water in villages (BAD, BADEA, BOAD, AFD, FDPCC projects see Soro (2002), Ahoussi (2008), Youan Ta (2008) and Soro (2010).

This present study aims to determine hydraulic properties of fractured reservoirs in Oumé's area (centre of Côte d'Ivoire) and estimate transmissivity parameter by using geostatistical approach.

Study area: The study area is localized in Oumé department, at centre of the Côte d'lvoire. Its surface covers about 2000 kilometers square and is ranging between longitudes $5^{\circ} 10^{\prime}$ and $5^{\circ} 50^{\prime} \mathrm{W}$ and latitudes $6^{\circ} 10^{\prime}$ and $6^{\circ} 40^{\prime} \mathrm{N}$ (figure 1). Relief is monotonous with large plains surmounted by small inselbergs at south sector. The hydrographic network of this area is dense and constituted principally of Bandama and Marahoué rivers. In geological viewpoint, the Oumé area is part of the Baoule-Mossi domain, at eastern major fault of Sassandra River. Geological formations have been structured during eburnean orogenesis (figure 1). Geological units can be subdivided in two groups (Arnould, 1961 ; Tagini, 1971 ;Géomines, 1982, Yacé, 2002):

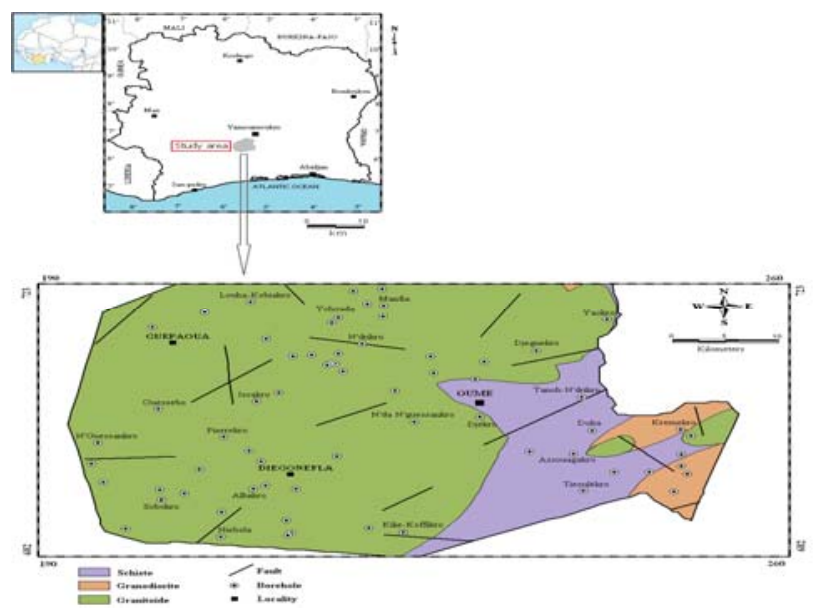

A geological log of the study area

Fig 1 : Geological map and location of the boreholes on the study area.

- volcano-sedimentary, that includes two subsets : i) flyschoides, constituted of flyschs, schistss, meta sediments and undifferentiated rocks ;ii) and metavulcanites constituted by amphibolites, andesite, spilites, conglomerates and grauwackes. In this whole, schistss constitute the most predominant geological formations.

- and the granitoides, which are essentially constituted by granites and granodiorites.

The granitoides and metamorphic rocks occupied respectively $84 \%$ and $16 \%$ of the study area.

On tectonics viewpoint, the area has been affected by several tectonic phases which developed fracture networks in these formations. Fracturing is more developed in the volcano-sedimentary complex than on the granitoides. Fractures are generally straight and sub-vertical. These fractures would have replayed several times during their geological history (Géomines, 1982 ; Faillat, 1986).

Data and methods: Available data in this study came from geological map at 1/200 000 of Oumé area (Géomines, 1982) and boreholes technical sheets from BOAD-3, BAD and FDPCC projects for the water supply during 1996-2004's period. Boreholes coordinates come from technical sheets and used for establishment of boreholes distribution map (figure 1). These technical sheets give some information on discharge, tickness of weathered zone, depth of the hydraulically fracture active (inflow), depth of the boreholes, pumping data, etc.

The boreholes are isolated wells and capture groundwater resources contained in the fractured aquiferes, on which pumping test have been executed. The study presented here only relates to wells tapping the fractured crystalline and metamorphic aquifers in the of Oumé area. The distribution of wells is not homogeneous on the whole domain. Transmissivity has been calculated using the Theis recovery method (Theis, 1935) in order to reduce the effect of turbulent head loss in the well bore and gravel pack as suggested by many authors (Kawecki, 1993, 1995a). Transmissivity values obtain in this approach is more reliable and satisfactory because the flow inside of aquifer is not influenced.

Specific capacity was evaluated at the end of the third step after 12 hours of pumping. Indeed, the pumping tests lasting less than $12 \mathrm{~h}$ were not kept. Drawdowns were corrected for turbulent head losses before evaluating the specific capacity as suggest by many authors (Jalludin et Razack, 2004; Razack and Lasm, 2006, Srivastav et al., 2007; 
Rotzoll and El-Khadi, 2008). Turbulent head losses were calculated by interpreting the step drawdown tests (Driscoll, 1986; Kruseman and de Ridder, 1990).

Data base include 65 boreholes where transmissivity and specific capacity are determinated. These boreholes were retain because of their data were reliable.

Different parameters have been studied in order to know their influence on the aquifer productivity, such as the petrography nature of rocks, the depth of inflow, the transmissivity and the specific capacity.

Transmissivity data have been treated according a statistical and geostatistical analysis viewpoint. Statistical distribution law of this parameter is study and its assessment estimate of with kriging method.

The variogram allows to describe the spatial structure of the variable and to see the deterioration of the correlation between the measured points when the distance increases. Variogram allows making the passage from local knowledge to regional knowledge. Variogam is defined by the equation (1) :

$\gamma(\mathrm{h})=\frac{1}{2} \mathrm{E}\left[(\mathrm{Z}(\mathrm{x}+\mathrm{h})-\mathrm{Z}(\mathrm{x}))^{2}\right]$

Where $\mathrm{h}=\mathrm{xi}-\mathrm{xj} ; \mathrm{E}:$ mathematical expectation; $\gamma$ $(h)$ is a semi-variogram.

Experimental variogram is analysed near the origin and at large distances of $h$. Behaviour of the variogram near the origin gives information about discontinuity or nugget effect of the study samplings. Generally, nugget effect on experimental variogram is indicative of micro structuring at a scale which is smaller than scale of study samplings (i.e. microvariability) or it may indicate measurement errors (Razack, 1984 ; Massoud, 1988 ; Lasm, 2000; Razack and Lasm, 2006). Practically on an experimental variogram, it is difficult to separate the nugget effect in microstructure and of the measurements errors. The behaviour of the variogram at large distances, allows determining if the spatial variable studied is stationary. For such stationary variable, the experimental variogram should stabilise around a value called the sill $\left(\mathrm{C}=\mathrm{C}_{0}+\mathrm{C}_{1}\right)$. The range represents the value of $h$ where the sill is obtained on the variogram. Beyond this distance, two point measurements of the spatial variable become uncorrelated.

The kriging technics can thereafter be used to perform an assessment of the spatial variable over the whole study domain. Kriging takes into account the spatial structure of the variable, characterized through the experimental variogram, which should previously be adjusted by a theorical analytical model (Razack and Lasm, 2006; Lasm et al., 2008). A simplified presentation of the kriging theory is given hereunder. Interested readers can find more detailed presentations on this theory in the following references (Journel and Huijbregts, 1978; Myers, 1982 ; Razack, 1984 ; Isaaks et Srivastava, 1989; Kitanadis, 2000; Clark et Harper, 2000).

After that variogram model is chosen, this variogram will be valid by cross validation procedure. This procedure is described in details in (Clark, 1986 ; Isaak and Srivastava, 1989 ; Gascuel-Odoux et al., 1994 ; Razack and Lasm, 2006). Cross validation compares actual values with estimates values and comprises the steps consisting in (Razack and Lasm, 2006) : (i) eliminating a single value from the data set, (ii) kriging (or cokriging) an estimate $\left(Z^{*}\right)$ at this location using the surrounding values, (iii) calculating the actual error using $\left(Z-Z^{*}\right)$ (actual value-estimated value), and (iv) finding out the theoretical error using the kriging (or cokriging) variance (or its square-root, the standard deviation).

If the structural models are valid, the following results should be obtained:

$$
\begin{aligned}
& \frac{1}{N} \sum_{i=1}^{N}\left(Z_{i}^{*}-Z_{i}\right)=0 \\
& \frac{1}{N} \sum_{i=1}^{N}\left(Z_{i}^{*}-Z_{i}\right)^{2}=\text { minimum } \\
& \left\{\frac{\frac{1}{N} \sum_{i=1}^{N}\left(Z_{i}^{*}-Z_{i}\right)^{2}}{\frac{1}{N} \sum_{i=1}^{N} \sigma_{i}^{2}}\right\}=1
\end{aligned}
$$

The average of the actual errors should be zero (Eq. 2) and their variance should be a minimum (Eq. 3). The variance ratio of the actual errors to the average kriging (or cokriging) variance (Eq. 4) should be one. 
For this study we have used GEO-EAS software (Englund and Sparks, 1991) to perform geostatistics analysis.

\section{RESULTS}

Productivity of the reservoirs: The depth of the boreholes range from 39 to $93 \mathrm{~m}$ below the ground surface with overall an average of $60 \mathrm{~m}$. Analysis of borehole logs permits to identify several inflows. These inflows are characterised by variable discharge, there are most with an important discharge whereas others are not with small discharge. Therefore inflows are not the same interest. Borehole logs show an increase of inflows with depth. An example of geological log is illustrated on the figure $2 a$.
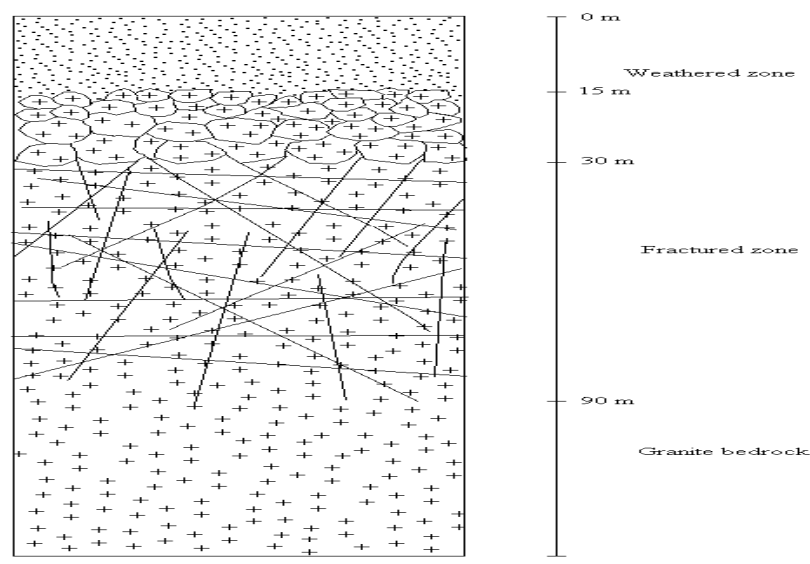

The first inflows into boreholes of Oumé area are met between 1 and $63 \mathrm{~m}$ from the top of crystalline basement i.e. below weathered zones (between 10 and 72 from topographic surface). They are productive fractures, they present a good properties of geometric parameters. The most productive zones $\left(Q \geq 5 \mathrm{~m}^{3} \cdot \mathrm{h}^{-1}\right.$, following Inter-african Committee of Hydraulic Studies CIEH (1978) classification) are located at depth range 40-50 m from the top of crystalline basement (fissured zone). Beneath this zone, the inflow rate into boreholes decreases (figure $2 \mathrm{~b}$ ). Overall, the discharge of the different boreholes range between $0.5 \mathrm{~m}^{3} / \mathrm{h} \leq \mathrm{Q} \leq$ $20 \mathrm{~m}^{3} / \mathrm{h}$. The proportional categorization is as follows: ( $n=65$ boreholes) (figure 3 ):

- $\mathrm{Q}<2.5 \mathrm{~m}^{3} \cdot \mathrm{h}^{-1}$ represent $60 \%$ of the boreholes ;
- $2.5 \mathrm{~m}^{3} \cdot \mathrm{h}^{-1} \leq \mathrm{Q} \leq 5 \mathrm{~m}^{3} \cdot \mathrm{h}^{-1}$ represent $17 \%$ of the boreholes ;

- $\mathrm{Q}>5 \mathrm{~m}^{3} \cdot \mathrm{h}^{-1}$ represent $23 \%$ of the boreholes.

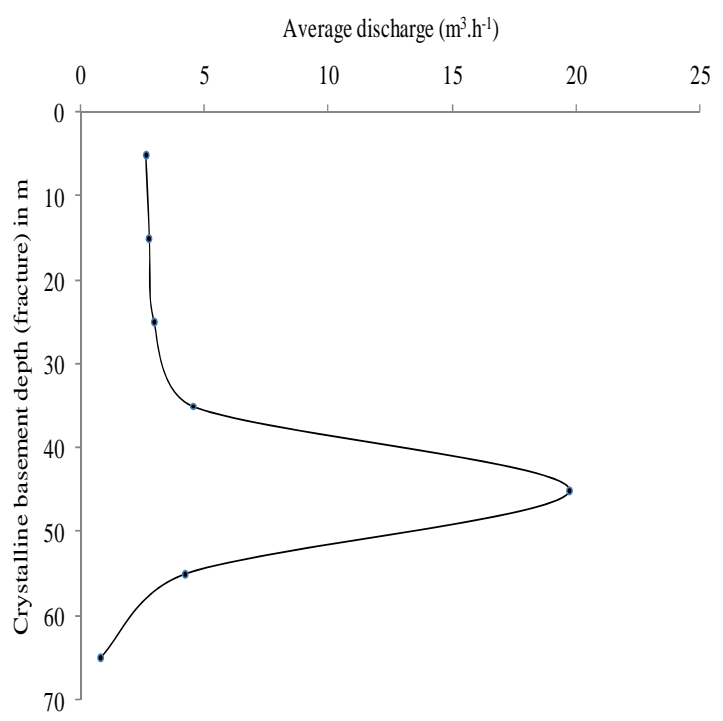

Fig 2b : Relation between crystalline basement depth (fracture) and average discharge.

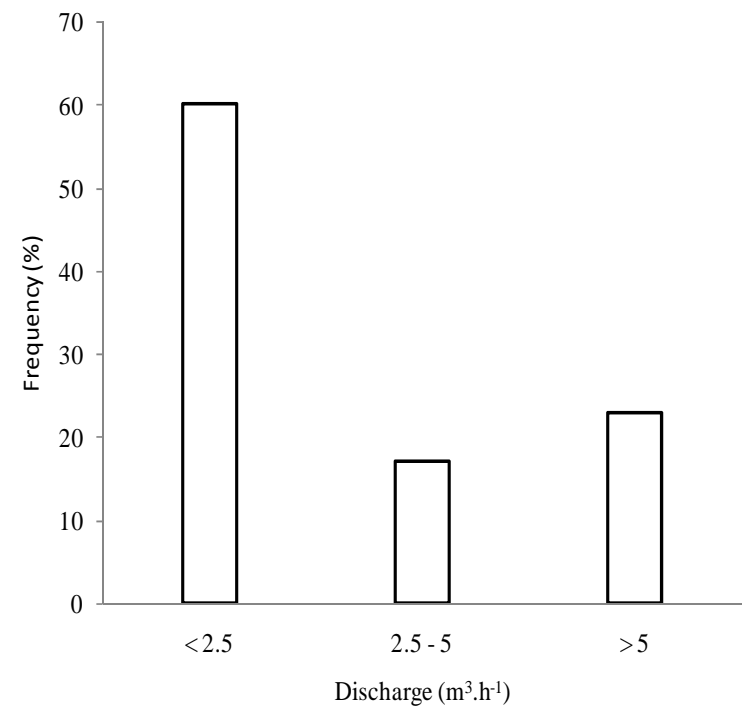

Fig 3 : Frequency distribution of discharge.

Discharge spread on several orders of magnitude and are therefore very variable. Number of inflows varies at 1 to 4 with an average of 2 inflows by boreholes. These inflows are not all equivalent, some are more productive than of others. Beyond 
$63 \mathrm{~m}$ of depth, number of inflows decreases considerably.

Productivity of these inflows depends of geometric properties of the fracture networks (aperture, filling, connectivity, etc.) acquired during tectonics events, of tectonic intensity, of weathered zone thickness and the bed rock lithology. However, it's not excluded to meet some inflows with a discharge more important at very high depths. Besides, the boreholes can have only an inflow with a discharge more productive than a borehole presenting several inflows.

Analysis of average discharge of the inflows by slices of depth indicates that most productive inflows are met between 40 and $50 \mathrm{~m}$ (from top of crystalline basement). The average discharge increases progressively to reach the maximum at $19.7 \mathrm{~m}^{3} \cdot \mathrm{h}^{-1}$ between 40 and $50 \mathrm{~m}$, then decrease with the depth of boreholes to reach $1 \mathrm{~m}^{3} \cdot \mathrm{h}^{-1}$ at 63 $\mathrm{m}$. Beyond this depth inflows become scarce.

Rocks lithology in which is performed boreholes can influence discharge, because the geometry of the fractures network is specific to every rock lithology. Fractures will tend to present better geometric properties in types of rocks that in others. There are respectively 9 and 51 boreholes in the schistss and the crystalline rocks. The borehole number in the schistss has not permit to make a statistical analysis on productivity viewpoint. Important discharges $\left(Q>15 \mathrm{~m}^{3} \cdot \mathrm{h}^{-1}\right)$ are met in schists as well in crystalline rocks.
Transmissivity and specific capacity analysis: Specific capacity values oscillate between 0.01 and $2.11 \mathrm{~m}^{2} . \mathrm{h}-1$, spread over 3 orders of magnitude with an average of $0.30 \mathrm{~m}^{2} \cdot \mathrm{h}^{-1}$.

These specific capacity values are generally low. On the study sampling, only $5(7.69 \%)$ presents a specific capacity superior to $1 \mathrm{~m}^{2} \cdot \mathrm{h}^{-1}$ and 10 are superior to $0.5 \mathrm{~m}^{2} \cdot \mathrm{h}^{-1}$ (15.68 \%).

Specific capacity oscillates between 0.01 to 0.3 $\mathrm{m}^{2} \cdot \mathrm{h}^{-1}$ and 0.01 to $2.11 \mathrm{~m}^{2} \cdot \mathrm{h}^{-1}$ respectively in the schists and the crystalline rocks. The specific capacity is generally important in crystalline rocks than in the schistss because average of values is respectively 0.12 and $0.32 \mathrm{~m}^{2} \cdot \mathrm{h}^{-1}$. Consequently, productivity should be better in crystalline rock of Oumé's area. Transmissivity values range between 0.004 and $4.607 \mathrm{~m}^{2} \cdot \mathrm{h}^{-1}\left(1.08 \mathrm{E}-06 \mathrm{~m}^{2} . \mathrm{s}^{-1}\right.$ and $1.28 \mathrm{E}-$ $\left.03 \mathrm{~m}^{2} . \mathrm{s}^{-1}\right)$ with an average of $0.558 \mathrm{~m}^{2} . \mathrm{h}^{-1}(1.52 \mathrm{E}-$ $04 \mathrm{~m}^{2} . \mathrm{s}^{-1}$ ), spraying on several orders of magnitude and reflect the heterogeneity of these aquifers. About $80 \%$ of boreholes have a transmissivity superior to $1 \mathrm{E}-05 \mathrm{~m}^{2} \cdot \mathrm{h}^{-1}$. Transmissivity are more important in the crystalline rocks than in the schists formations. The summary statistics of these two variables are summarized in the table 1.

Frequency of distributions of the logarithm transformed variables $(\log T$ and $\log Q / s)$ on a arithmetic diagram plotted in figures 4 and 5 . These diagrams clearly indicate that both variables ( $T$ and $\mathrm{Q} / \mathrm{s}$ ) are lognormally distributed. A KolmogorovSmirnov test shows that the lognormal adjustment is acceptable at threshold of $10 \%$.

Table 1: Summary statistics of transmissivity $\left(T, \mathrm{~m}^{2} \cdot \mathrm{h}^{-1}\right)$ and specific capacity $\left(\mathrm{Q} / \mathrm{s}, \mathrm{m}^{2} \cdot \mathrm{h}^{-1}\right)$ data

\begin{tabular}{|c|c|c|c|c|c|c|}
\hline & Number & Maximum & Minimum & Average & $\begin{array}{c}\text { Standard } \\
\text { deviation }\end{array}$ & $\begin{array}{c}\text { coefficient of } \\
\text { variation }(\%)\end{array}$ \\
\hline $\mathrm{T}$ & 65 & 4.607 & 0.004 & 0.548 & 0.863 & 157.412 \\
\hline $\mathrm{Q} / \mathrm{s}$ & 65 & 1.920 & 0.005 & 0.272 & 0.363 & 133.605 \\
\hline $\log \mathrm{T}$ & 65 & 0.663 & -2.410 & -0.800 & 0.771 & -96.374 \\
\hline $\log \mathrm{Q} / \mathrm{s}$ & 65 & 0.283 & -2.275 & -0.838 & 0.497 & 59.296 \\
\hline
\end{tabular}


Am. J. Sci. Ind. Res., 2011, 2(2): 310-322

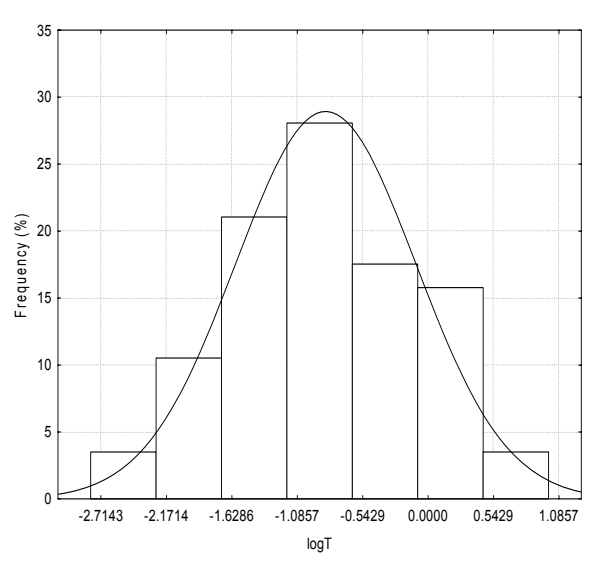

Figure 4 : Frequency distribution of $\log T$ in arithmetic diagram.

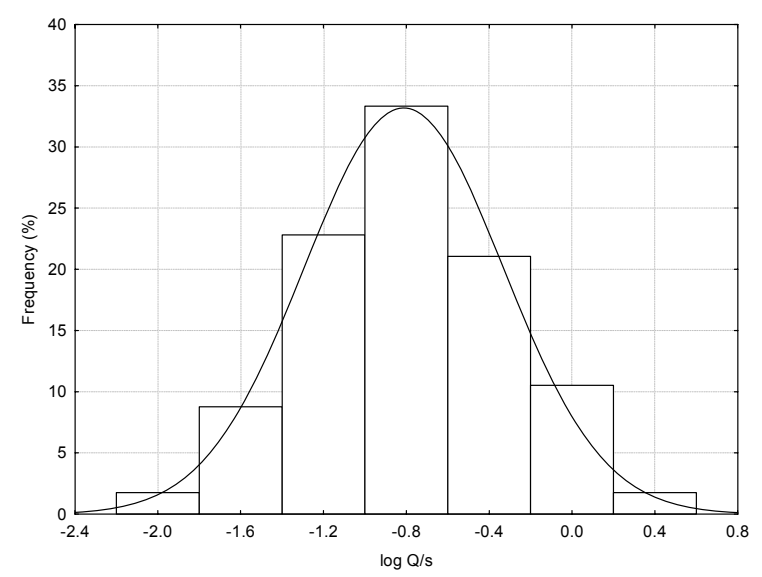

Fig 5: Frequency distribution of $\log Q / \mathrm{s}$ in arithmetic diagram.

Goestatistical analysis of transmissivity: Experimental variogram of tranmissivity values $(\log T)$ is calculed and presented on figure 6 . Variogram is characterising by a range, a sill and a nugget effect. This result indicates that experimental variogram is spatially structuring. The presence of the sill on the variogram indicates that the study phenomenon is stationary. Variogram clearly displays, near the origin a not significant nugget effect representing about $17 \%$ of total dispersion. It is a phenomenon fluently met in analysis of regionalized variables.

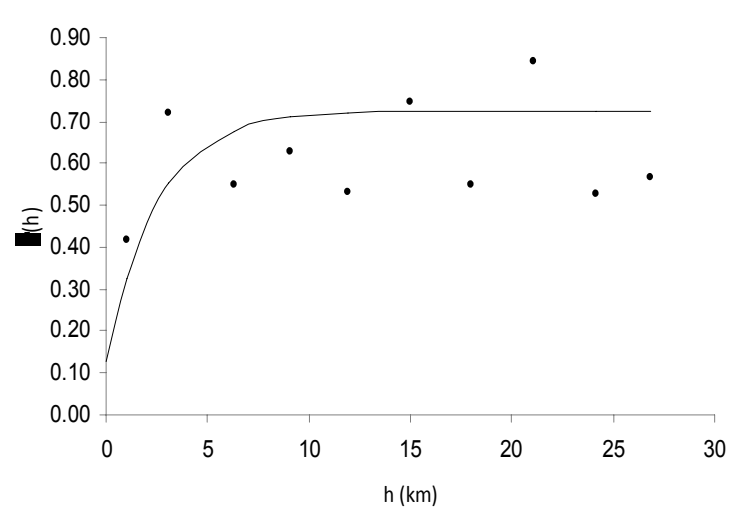

Fig 6 : Variogram of logT. Fitting with an exponential model.

Fitting of the theoretical model which the experimental variogram is done manually under GEOEAS software. Regionalization parameters of experimental variogram are determined according to the exponential model.

Practical range obtained in this study is equal to $\mathrm{a}=$ $7.5 \mathrm{~km}$, this range can be qualified of average. The modelling equation of the experimental variogram of $\log T$ is represented by the expression (5) :

$\gamma(h)=0.6 \times\left(1-\exp \left(\frac{-3 h}{7.5}\right)\right)+0.126$

Transmissivity estimation of the Oumé reservoirs by kriging: The variogram model given in equation (eq. 5) and the available logT sample data are used to perform a krigged estimation of $\log T$ over the study area with a mesh size of $5 \mathrm{~km} \times$ $5 \mathrm{~km}$. The estimate was made by using ordinary kriging $(\mathrm{OK})$ and the structural model of equation (eq. 5). A cross-validation of variogramms model (eq. 5) is carried out in order to check its validity. Its purpose is to analyse the estimation errors. Results of the cross validation procedure are reported in Table 2. Analyses of this table show that, crossvalidation procedure of the variogram presents reliable results, indeed the different condition of cross validation procedure are satisfied. The average of the actual error is equal to $\mathrm{Me}=0.0602$ and the ratio of the variances $\left(\sigma \mathrm{e}^{2} / \sigma_{\mathrm{K}}{ }^{2}\right)$ is close to 1 (1.0046). The variogram model used is therefore 
valid. The experimental variogram will be use to estimate the transmissivity in the study area.

Table 2: Cross validation results

\begin{tabular}{|l|c|c|c|c|c|c|}
\cline { 2 - 7 } \multicolumn{1}{c|}{} & Actual Log T & Kriged log T & Kriging SD & $\begin{array}{l}\text { kriging } \\
\text { variance }\end{array}$ & Actual error & $\begin{array}{l}\text { Actual } \\
\text { error/krg SD }\end{array}$ \\
\hline Minimum & -2.4100 & -1.4711 & 0.4773 & 0.2278 & -1.7906 & -2.2866 \\
\hline Maximum & 0.6600 & -0.1096 & 0.9509 & 0.9042 & 2.1849 & 2.5713 \\
\hline Average & -0.8002 & -0.7400 & 0.7916 & 0.6383 & 0.0602 & 0.0614 \\
\hline Variance & 0.5937 & 0.1155 & & & 0.6481 & 1.0703 \\
\hline SD & 0.7705 & 0.3398 & & & 0.8050 & 1.0346 \\
\hline
\end{tabular}

The frequency distributions of the actual errors $\left(\log T^{*}-\log T\right)$ on an arithmetic diagram are reported in figure 7 . It clearly shows that the distribution is normal. The different values of actual errors are centred on the value 0 , which indicate a symmetrical distribution of frequencies. A Kolmogorov-Smirnov test shows that the normal adjustment is acceptable at threshold of $10 \%$. This result is an indication of the model validity. Transmissivity values estimated with the equation 5 range between 0.045 and $0.869 \mathrm{~m}^{2} . \mathrm{h}^{-1}$ (1.26E-05 and $2.41 \mathrm{E}-04 \mathrm{~m}^{2} . \mathrm{s}^{-1}$ ), spraying on two orders of magnitude.

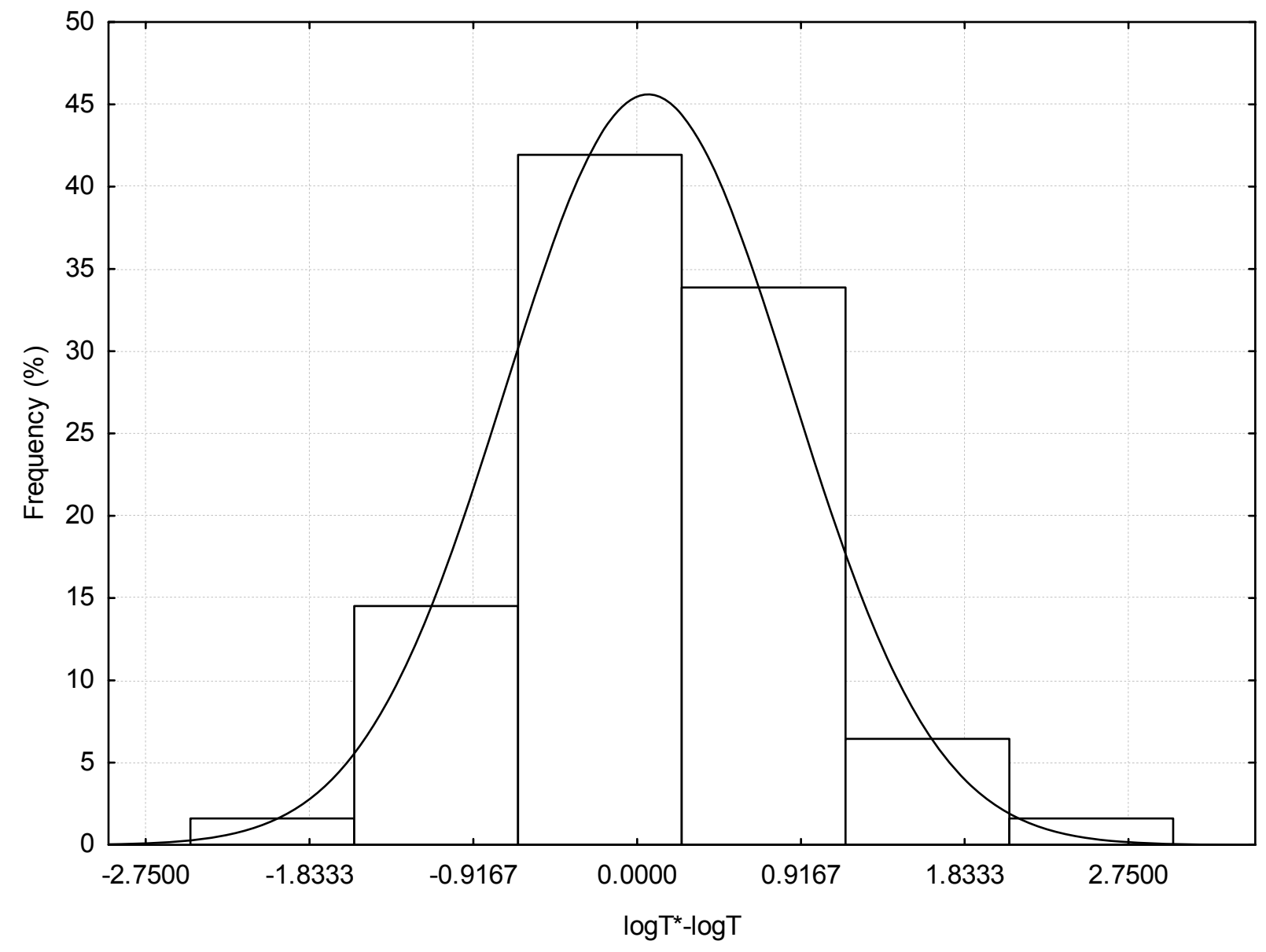

Fig 7 : Actual error frequency distribution of logT in arithmetic diagram 
Am. J. Sci. Ind. Res., 2011, 2(2): 310-322

The amplitude of estimated values of $T$ (after backtransform) is reduced compared to the actual values of $T$. The observed $T$ values span on four orders of magnitude, while the estimated values span only on two orders of magnitude. This might be due to the extreme values of actual values which are very few on the one hand and the smoothing effect of kriging on the other hand.

Kriging estimation and standard deviation of $\log T$ are illustrated respectively on figures 8 and 9 . The map of estimation present in certain places a more and less smoothed aspect, a feature which is usually met in the estimation of regionalized variable. The standard deviation values oscillate between 0.538 and 0.932 , they vary from the simple to the double. Therefore, standard deviation values are not everywhere identical. Highest values of the standard deviations of estimate are found towards the limits of the study area and in the areas where very few data are available. These high values can be explained by skin effect and the presence of zones where data points are lacking. The smaller the standard deviation value, the higher the accuracy of estimates.

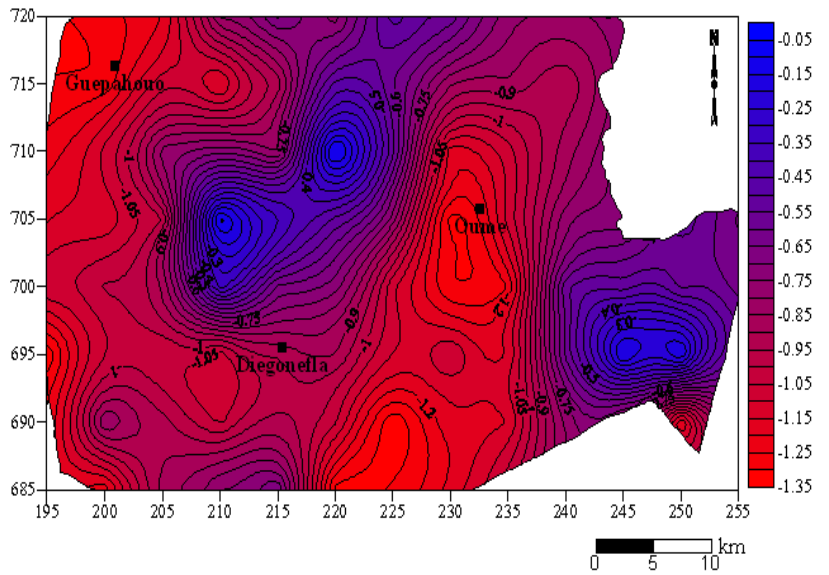

Fig 8: Krigged logT map

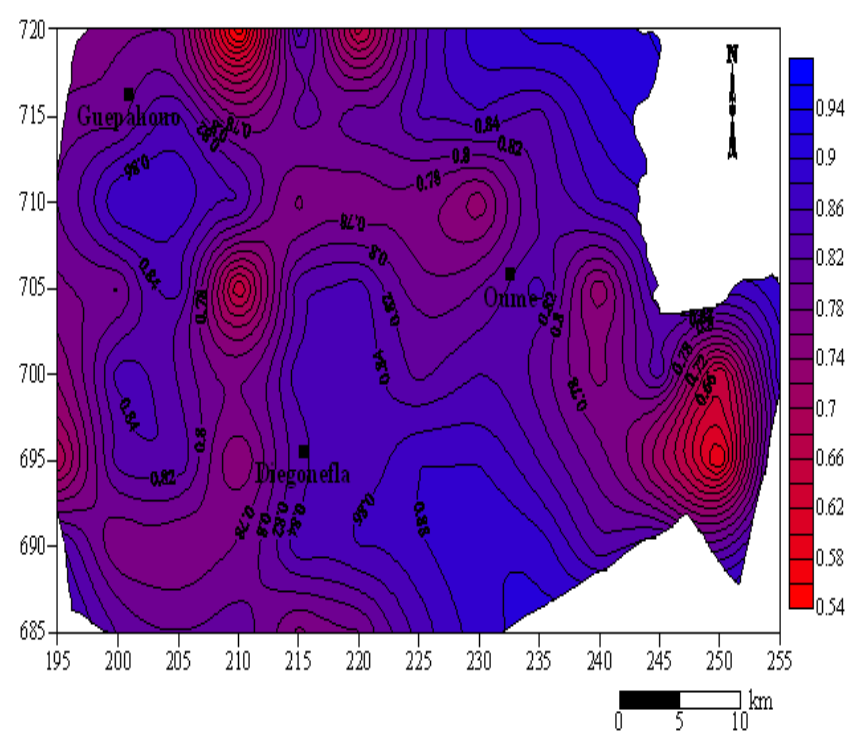

Fig 9 : $\log$ T kriging standard deviations map.

The standard deviation map is an indicator of the quality of the kriging estimation values. Outside of the zones where standard deviation values are high, the $\log T$ estimation is everywhere better on the area study.

The estimated transmissivity values map is illustrated to the figure 10. Generally, the estimated transmissivity values are compatibles to the observed values (actual values). Kriging reconstitutes the high values as well that the low values of the transmissivity.

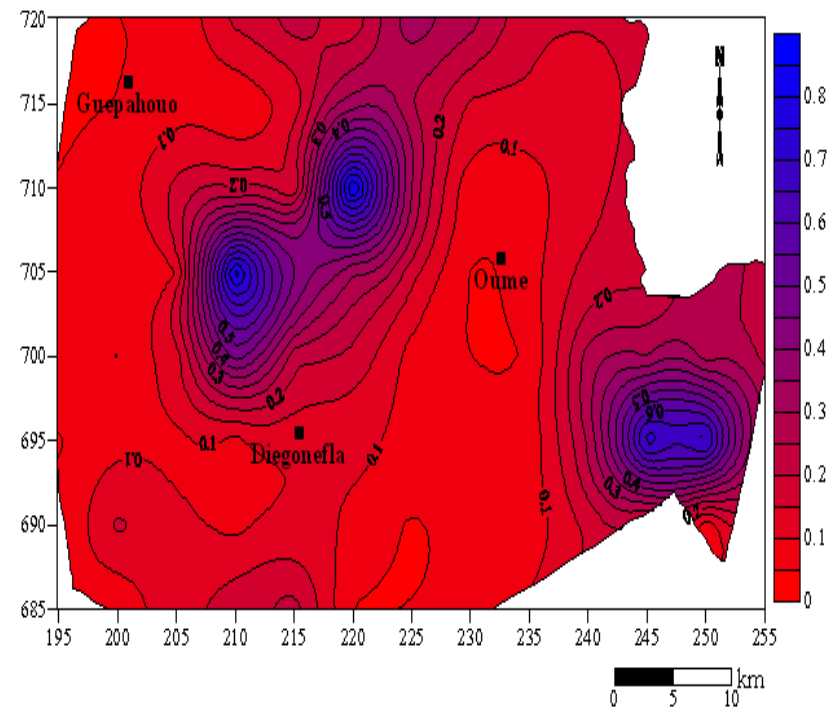

Fig 10: Transmissivity estimation map obtained by a backtransform logT to $\mathrm{T}$. 


\section{DISCUSSION}

Precambrien crystalline basement of Côte d'Ivoire is fractured abundantly which is attested by works of many authors (Faillat, 1986; Biémi, 1992 ; Savané, 1997; Djro, 1998 ; Lasm, 2000 ; Lasm and Razack, 2001 ; Jourda, 2005 ; Jourda et al., 2006; Youan Ta, 2008 ; Youan Ta et al., 2008; Kouamé et al., 2009). Most important part of groundwater resources of this country is contained in crystalline basement fractured reservoirs (Biémi, 1992 ; Lasm, 2000; Jourda, 2005; Jourda et al., 2006; Youan Ta, 2009 ; Soro, 2010) . Indeed, crystalline basement in Côte d'Ivoire represents about $97.5 \%$ of the land area. Fractures developed in the crystalline basement by different tectonic events have not the same interest on hydraulic viewpoint because of permeabilities developed by these fractures. Indeed, some fractures can be sterile (closed fractures, secondary recrystallization i.e. vein, etc.) and others are conductive. The failure of rate in the identified fracturing is very low, this rate is generally inferior to $10 \%$ when the wells tap fractured crystalline and metamorphic aquifers. Faillat (1986) indicates that if fractures are not reactivated, they will tend to fill whereas the neo-formed fractures will have more of luck to play an important hydrogeological role. Importance of these fractures for hydrogeologist is the role that is devolved to them on hydraulic viewpoint.

Productivity of fractured reservoirs has been explained by geometric properties of fractures and rock lithology. Indeed, these parameters influence water productivity as it is the case here. Similar studies have been achieved in various areas of Côte d'Ivoire : La Me area (Soro, 1987), High Marahoué area (Biémi, 1992), Odienné area (Savané et al., 1993; Savané et al., 1997), Man-Danané area (Lasm, 2000; Lasm et al., 2004), Korhogo area (Jourda et al., 2006), Aboisso area (Dibi et al., 2004). The synthesis of these works on aquifer productivity in crystalline basement area shows that aquifers of schistss are the most water productive in a few cases. However, in the Oumé area, the productivity of aquifer of crystalline rocks is better than productivity in the schistss. In this area we have luck ( $80 \%$ of probability) to meet a sufficient discharge $(Q$ $>1 \mathrm{~m}^{3} \cdot \mathrm{h}^{-1}$ ) for water supply for farming populations in theses two family of rocks. In Man-Danané area, Lasm (2000) and Lasm et al. (2004) indicate that the most productive reservoirs were charnockites and granulites. These two domains (Man and BaouleMossi) have not the same geological and tectonic contexts. The geological history of Man-Danané and Oumé regions inscribes respectively in those of the Keneman-Man (archean) and Baoule-Mossi domains (Proterozoic). These two domains separated by the major fault of Sassandra that played an important role in isolation of the archean core of Côte d'Ivoire in term of eburnean tectonic constraints (Camil, 1984). The archean core is characterized by a complex tectonic and this tectonic is polyphased (Papon and Lemarchand; 1973; Camil, 1984 ; Djro, 1998). This tectonic had led to a very developed fracturing in archean rocks. Archean core of Man-Danané area is the most fractured zone of Côte d'Ivoire. Tectonic was develop a good geometric properties in theses fractures (Biémi, 1992 ; Lasm, 2000) and has contributed to the definition of hydraulic behaviour of fractures. Indeed, the aquifers in archean area are very productive than the aquifers of others areas in proterozoic domain (Lasm, 2000 ; Lasm et al., 2004). The best productivity recorded in crystaline rocks in this study finds its explanation in the good hydraulic properties of their fractures acquired during different tectonic events. In the schists, the presence of fine shale particles is favourable to reduce discharge of inflows (Berger et al., 1981 ; Fahy, 1981). This can explain the smaller discharge met generally in this formation. The productivity of aquifers varies therefore according to petrographic type of rocks.

The smaller discharges generally met in some programs of waters supplies for farming populations can be explained by the quality of hydrogeological studies before carrying out boreholes. Indeed, the boreholes are implanted solely on geomorphologic considerations (Faillat, 1986 ; Lasm, 2000; Lasm et al., 2004). Geophysical and remote sensing approaches are used when the failure rate of boreholes performing with geomorphological approach is high i.e. more $50 \%$. The rate of failure is generally important and the specific capacity are low (Faillat, 1986 ; Biémi, 1992). Specific capacities are overall inferior to $1 \mathrm{~m}^{2} \cdot \mathrm{h}^{-1}$ and exceed rarely $2 \mathrm{~m}^{2} \cdot \mathrm{h}^{-1}$ (Faillat, 1986). In farming zones of Côte d'Ivoire, searching of important discharge is not necessary (Soro, 1987). This author indicates that a discharge superior to $1 \mathrm{~m}^{3} . \mathrm{h}^{-1}$ can be considered sufficient for water supply for farming populations. On the other hand in some important cities, the research are focused on the important discharges, what implies some advanced studies in hydrogeological viewpoint by using geophysics, photogeology and remote sensing approaches. Some discharges obtained in this study can be improved while coupling these different techniques. 
Transmissiviy and specific capacity obtained in this study are compatibles with those met in crystalline basement of West Africa generally and those of other areas of the country in proterozoic domain (locate at the eastern Sassandra fault) in particular : Korhogo (1E-04 and 8.33E-05 $\mathrm{m}^{2} . \mathrm{s}^{-1}$, Degallier (1977)), IRHO $\mathrm{La} \mathrm{Me}$ (1E-04 to 1E-06 m $\mathrm{m}^{2} . \mathrm{s}^{-1}$, Soro (1987)), Yamoussoukro (1E-03 and 1E-06 m $\mathrm{m}^{2} \cdot \mathrm{s}^{-1}$, Faillat (1986)), High Marahoué (1E-04 and 1E-07 $\mathrm{m}^{2} \cdot \mathrm{s}^{-1}$, Biémi, (1992)). Transmissivity calculated in Oumé's area spread on four orders of magnitude putting in evidence the heterogeneity of media. Transmissivity and specific capacity are distributed following lognormal low. The lognormality of the transmissivity and the specific capacity is well recognised in the literature (Bracq and Delay, 1997; Fabbri, 1997; Jalludin and Razack, 2004; Razack and Lasm, 2006 ; Lasm et al., 2008).

The geostatistical analysis of the transmissivity values $(\log T)$ underlines that spatial distribution of this variable is not random but it present a spatial structuring. Variable logT behaves like a regionalized variable. The practical range $(a=7.5 \mathrm{~km})$ can be explained by the important inter-connectivity of fracture networks in study area (Razack and Lasm, 2006; Lasm et al., 2008). Similar studies undertaken in various areas of Côte d'Ivoire (Lasm, 2000 ; Soro et al., 2001, Jourda, 2005 ; Razack and Lasm, 2006 ; Lasm et al., 2008; Youn Ta, 2008) gave comparable results. Actual values and kriging estimed values (after backtransform) are comparable and reliable. The actual values oscillate between $4 \mathrm{E}-03$ and 4.607 $\mathrm{m}^{2} \cdot \mathrm{h}^{-1}\left(1.08 \mathrm{E}-06 \mathrm{~m}^{2} . \mathrm{s}^{-1}\right.$ and $\left.1.28 \mathrm{E}-03 \mathrm{~m}^{2} . \mathrm{s}^{-1}\right)$ while the estimated values oscillate between $4.5 \mathrm{E}-02$ and 8.69E-01 $\mathrm{m}^{2} \cdot \mathrm{h}^{-1}\left(1.26 \mathrm{E}-05\right.$ and $\left.2.41 \mathrm{E}-04 \mathrm{~m}^{2} \cdot \mathrm{s}^{-1}\right)$. The average values are respectively of $1.52 \mathrm{E}-04 \mathrm{~m}^{2} . \mathrm{s}$ ${ }^{1}$ and $5.12 \mathrm{E}-05 \mathrm{~m}^{2} . \mathrm{s}^{-1}$. Extreme values and effect of smoothing explain reduction of orders of magnitude of estimated values from four to two.

These results indicate that on statistical viewpoint, estimated transmissivity values and actual values are similar. Geostatistical procedure satisfies distribution of high and low values of transmissivity in relation with available knowledge. On this basis, estimates of transmissivity in Oumé's region are proved coherent and acceptable.

The accuracy of the estimated transmissivity map can be, to some extent, interpreted with the use of the kriging standard deviation related to $\log T$ kriging. We can assume that at zones where $\log T$ estimates are not reliable, estimates of $\mathrm{T}$ are also not reliable. Accordingly, towards the boundaries of study area, kriging standard deviations increase gradually. Thus estimates become less and less reliable. It is the example of north-eastern and southern sectors. These estimations in these sectors are less reliable than those in central zone.

\section{CONCLUSION}

The present study aims at better knowledge of the hydraulic properties from fractured reservoirs in Oumé's area and the estimate of the transmissivity on the whole domain by kriging techniques. The main findings of this study are summarised as follows :

1. boreholes are performed in crystalline and metamorphic rocks with depth varying between 39 to $93 \mathrm{~m}$. These boreholes present many inflows with variable discharge.

2. inflows are located between 1 and 63 meters of depth beneath the weathered zone. The productive fractures are located between 40 and $50 \mathrm{~m}$ of depth which discharge generally superior to $5 \mathrm{~m}^{3} \cdot \mathrm{h}^{-1}$

3. Aquifers in crystalline rocks are most productive than those in the schists;

4. transmissivity and specific capacity calculated range between $1.08 \mathrm{E}-06$ and $1.28 \mathrm{E}-03 \mathrm{~m}^{2} \cdot \mathrm{s}^{-1}$ and 0.01 to $2.11 \mathrm{~m}^{2} \cdot \mathrm{h}^{-1}$ respectively. They spread on several orders of magnitude highlighting heterogeneity of aquifer of Oumé's area ; both are distributed following lognormal low ;

5. $\log T$ behaves like a regionalized variable geostatistical viewpoint. Experimental variogram presents a structuring with a nugget effect representing $17 \%$ of total dispersion. Practical range is equal to 7.5 $\mathrm{km}$, which indicate a mean structuring ;

6. cross-validation results showed that conditions of unbiasedness and optimality are met for the experimental variogram model. The variogram model used in this study is valid. The average of the actual error and the ratio of the variances $\left(\sigma \mathrm{e}^{2} / \sigma_{\mathrm{K}}{ }^{2}\right)$ are close to 0 and $1\left(\mathrm{Me}=0.0602 ; \sigma \mathrm{e}^{2} / \sigma_{\mathrm{K}}{ }^{2}=\right.$ 1.0046) respectively ;

7. available data of $\log T$ permitted an assessment of this parameter by kriging on the whole of study area. The estimated transmissivity values oscillate between 1.26E-05 and 2.41E-04 $\mathrm{m}^{2} \cdot \mathrm{s}^{-1}$, with an average of $5.1 \mathrm{E}-05 \mathrm{~m}^{2} \cdot \mathrm{s}^{-1}$;

8. comparison of actual values ( $\log T)$ and the estimated values $\left(\log T^{*}\right)$ on statistical 
viewpoint underlines that these data are similar except extreme values ;

9. standard deviation values are appreciably important towards the boundaries of the study area and in the zone where data available are poor or are very few ;

10. estimated transmissivity values $\left(T^{*}\right)$ are generally satisfactory and can be accepted.

The geostatistical approach proved useful to provide a reliable estimation of the transmissivity of the Oumé fractured aquifers. This approach incorporates available data of the transmissivity. The transmissivity map will be used as an input for forthcoming model to manage optimally water resources in Oumé's area. These results constitute a large contribution of the best knowledge of the fractured reservoirs in the crystalline basement of Côte d'Ivoire.

\section{ACKNOWLEDGEMENTS}

The authors would like to gratefully thank the anonymous reviewers for their comments and suggestions, and to responsibles of the Department of Ministry of economic infrastructures of the Oumé area (Côte d'Ivoire) for the data used in this study.

\section{REFERENCES}

Ahoussi, K.E (2008). Evaluation quantitative et qualitative des ressources en eau souterraines dans le sud de la Côte d'Ivoire): Application de l'hydrochimie et des isotopes de l'environnement à l'étude des aquifères continus et discontinus de la région Abidjan-Agboville. PhD Thesis, University of Cocody-Abidjan (Côte d'Ivoire), $270 \mathrm{p}$.

Arnould M. (1961). Etudes géologiques des migmatites et des granites précambriens du Nord-est de la Côte d'Ivoire et de la Haute-Volta méridionale. Bull. DMG, $\mathrm{n}^{\circ} 1,175 \mathrm{p}$.

Berger, J., Camerlo, J., Fahy, J. C., Haubert, M. (1981). Etude des ressources en eaux souterraines dans une région de socle cristallin : la "Boucle de cacao " en Côte d'Ivoire. Bull. B.R.G.M., Sér. II, Sect. III, $n^{\circ} 4$ : 335-338.

Biémi, J. (1992). Contribution à l'étude géologique, hydrogéologique et par télédétection des bassins versants sub-sahéliens du socle précambrien d'Afrique de l'Ouest: hydrostructurale, hydrodynamique, hydrochimie et isotopie des aquifères discontinus de sillons et aires granitiques de la haute Marahoué (Côte d'Ivoire). PhD Thesis, University of Abidjan (Côte d'Ivoire), $493 \mathrm{p}$.

Bracq, P. and Delay, F. (1997). Transmissivity and morphological features in chalk aquifer: a geostatistical approach of their relationship. J. Hydrol., 191 : 139160.

Committee Inter african of Hydraulic Studies CIEH (1978). Méthode d'étude et de recherche de l'eau souterraine des roches cristallines de l'Afrique de l'Ouest. Vol.3.

Collin, J.J (1988). Eau souterraine, Santé publique et développement en Afrique sub-saharienne. Géol. 83$84: 44-48$.

Dibi, B., Inza, D., Goula, B.T.A, Savané, I. et Biémi J. (2004). Analyse statistique des paramètres influençant la productivité des forages d'eau en milieu cristallin et cristallophyllien dans la région d'Aboisso (sud-est de la Côte d'Ivoire). Sud Sci. \& Techn. 13 : 22-31.

Camil, J. (1984). Pétrographie, chronologie des ensembles granulitiques archéens et formations associées de la région de Man Côte d'Ivoire). Implication pour l'histoire géologique du craton Ouest-africain. PhD Thesis, University of Abidjan, Côte d'Ivoire, 306 p.

Clark, I. (1986). The art of cross validation in geostatistical applications. Proceedings of the $19^{\text {th }}$ International APCOM Symposium, Pennsylvania. State University, April, pp. 211-220.

Clark, I., Harper, W.V (2000). Practical Geostatistics 2000. Ecosse North America, Columbus, $\mathrm{OH}$.

Degallier, R. (1977). Détermination des paramètres hydrodynamiques de la nappe souterraine du bassin versant de Korhogo, d'après les variations de son niveau piézométrique. Bull. BRGM, Hydrogeol. Géol. Ing. , Sect. III, 3/4, $106 \mathrm{p}$.

Djro, S.C (1998). Evolution tectono-métamorphiques des gneiss granulitiques archéens du secteur de Biankouma. PhD Thesis, University of Abidjan, Côte d'Ivoire, $171 \mathrm{p}$.

Driscoll, F.G (1986). Groundwater and Wells. Reynolds Guyar Design Publisher Austin, Minnesota, 1089 p.

Englund, E., Sparks, A. (1991). GEO-EAS, Geostatistical Environmental Assessment Software. US Environmental Protec. Ag., 600/8-91/008, 186 p.

Fabbri, P. (1997). Transmissivity in the geothermal Euganean Basin: A geostatistical analysis. Ground Water 35 (5) : 881-887.

Fahy, J. C. (1981). Hydraulique villageoise en Côte d'Ivoire. situation au 30 septembre 1979. Bull. B.R.G.M., Sér. II, Sect. III, nº. 4 : 327-333.

Faillat, J.P (1986). Hétérogénéité et effet d'échelle dans les aquifères fissurés. Approche par pompage d'essai sur station expérimentale (Afrique de l'Ouest). Hydrogéol. 1: 65-76.

Gascuel-Odoux, C., Bovin, P., Walter, C. (1994). Eléments de géostatistiques. In: Des processus pédologiques. Ed. Actes, pp. 217-247. 
Géomines Ltée (1982). Inventaire hydrogéologique appliqué à l'hydraulique villageoise. Ministère des Travaux Publics et des Transports, Direction Centrale de l'Hydraulique, République de Côte d'Ivoire, carte de Gagnoa, Cahier n²4, 31 p.

Isaaks, E.H., Srivastava, M.R (1989). An introduction to applied geostatistics. Oxford University Press, New York, $561 \mathrm{p}$.

Jalludin, M., Razack, M. (2004). Assessment of hydraulic properties of sedimentary and volcanic aquifer systems under arid conditions in the Republic of Djibouti (Horn of Africa). Hydrogeol. J. 12 : 159-170.

Jourda, J.P.R (2005). Méthodologie d'application des techniques de télédétection et des systèmes d'information géographique à l'étude des aquifères fissurés d'Afrique de l'ouest. Concept de l'Hydrotechniquespatiale: cas des zones tests de la Côte d'Ivoire. PhD Thesis, University of CocodyAbidjan, Côte d'Ivoire, 429 p.

Jourda, J.P, Saley, M.B, Djagoua, E.V, Kouamé, K.J, Biémi, J., Razack, M. (2006). Utilisation des données ETM+ de Landsat et d'un SIG pour l'évaluation du potentiel en eau souterraine dans le milieu fissuré précambrien de la région de Korhogo (nord de la Côté d'Ivoire) : approche par analyse multicritère et test de validation. Télédét. 5(4) : 339-357.

Journel, A.G, Huijbregts, C.J (1978). Mining geostatistics. Academic Press, New York, 600 p.

Kawecki, M.W (1993). Recovery analysis from pumping tests with stepped discharge. Ground Water 31 (4) : 585-592.

Kawecki, M.W (1995). Meaningful interpretation of stepdrawdown test. Ground Water 33(1) : 23-32.

Kitanidis, P.K. (2000). Introduction to Geostatistics. Application in Hydrogeology. Cambridge Univ. Press, Cambridge, UK.

Kouamé, K.F., Lasm, T., De Dreuzy, J.R., Akaffou, A.G., Bour, O. et Davy, P. (2009). Contribution d'un modèle hydrogéologique à fractures discrètes à l'étude des aquifères fracturés du socle Archéen de Touba (NordOuest, Côte d'Ivoire). Rev. Sci. Eau 22 (5) : 617-632.

Kruseman, G.P., De Ridder, N.A (1990). Analysis and evaluation of pumping test data. International Institute for Land Reclamation and Improvement. Wageningen, The Netherland, $2^{\text {nd }}$ ed. (completely revised), $377 \mathrm{p}$.

Lasm, T. (2000). Hydrogéologie des réservoirs fracturés de socle: analyses statistique et géostatistique de la fracturation et des propriétés hydrauliques. Application à la région des montagnes de Côte d'Ivoire (Domaine archéen). PhD Thesis, University of Poitiers France, $273 \mathrm{p}$.

Lasm, T., Kouamé, F., Oga, M.S, Jourda, J.R P, Soro, N., Kouadio, H.B (2004). Etude de la productivité des réservoirs fracturés des zones de socle. Cas du noyau archéen de Man-Danané (Ouest de la Côte d'Ivoire). Rev. Ivoir. Sci. Technol. 5 : 97-115.

Lasm, T. and Razack, M. (2001). Lois d'échelle dans la fracturation des roches dures cristallines et dans le réseau hydrographique associé. C.R.A.S. Paris 333 : 225-232.

Lasm, T., Youan Ta, M. and Razack, M. (2008). Geostistical analysis of the transmissivity in fissured reservoirs of Bondoukou Region (northeast, Côte d'Ivoire). in the IAH-Selected Papers book series titled : Applied Groundwater Studies in Africa - Segun Adelana, Alan MacDonald, Tamiru Alemayehu \& Callist Tindimugaya (editors); Publishers: Taylor \& Francis, The Netherlands, pp. 473-485.

Massoud, H. (1988). Modélisation de la petite fracturation par les techniques de la géostatistique. Document B.R.G.M., pp. 155- 197.

Myers, D. (1982). Matrix formulation of co-kriging. Mathematic and Geology. Vol. 14, n.3, pp. 249-257.

Papon, A. et Lemarchand, R. (1973). Géologie et minéralisation du Sud-Ouest de la Côte d'Ivoire. Mémoire BRGM (Orléans, France) 80, 284 p.

Razack, M. (1984). Application des méthodes numériques à l'identification des réservoirs fissurés carbonatés en hydrogéologie. PhD Thesis, University of Montpellier (France), $384 \mathrm{p}$.

Razack, M. and Lasm, T. (2006). Geostatistical estimation of the transmissivity in a highly fractured metamorphic and crystalline aquifer (Man-Danane region, Western Ivory Coast). J. Hydrol. 325 : 164-178.

Rotzoll, K., El-Kadi ,A.I (2008). Estimating hydraulic conductivity from specific capacity for Hawaii aquifer, USA. Hydrogeol. J. 16 : 969-979.

Savané, I. (1997). Contribution à l'étude géologique et hydrogéologique des aquifères discontinus du socle cristallin d'Odienné (Nord-Ouest de la Côte d'Ivoire). Apports de la télédétection et d'un Système d'Information Hydrogéologique à Référence Spatiale (S.I.H.R.S.). PhD Thesis, University of Abidjan, Côte d'Ivoire, $386 \mathrm{p}$.

Savané, I., Benie, G.B, Hugh, G.J.Q et Biemi J. (1993). Application de la télédétection à la recherche des eaux souterraines en milieu cristallin : cas d'Odienné, Côte d'Ivoire. Télédétection des ressources en eau, Act. Journ. Sci., Tunis, pp. 111-120.

Savané, I., Doumouya, I. et Doumbia, L. (1997). Une approche à partir de modèles statistiques pour la détermination de la productivité des puits en contexte de socle cristallin dans la région d'Odienné (Côte d'Ivoire). Hydrogéol. 4 : 19-26.

Soro, G. (2010). Evaluation quantitative et qualitative des ressources en eau souterraines de la région des Lacs (Centre de la Côte d'Ivoire): Hydrogéologie et hydrochimie des aquifères discontinus du district de 
Am. J. Sci. Ind. Res., 2011, 2(2): 310-322

Yamoussoukro et du Département de Tiebissou. PhD Thesis, University of Abidjan - Côte d'Ivoire, 250 p.

Soro, N. (1987). Contribution à l'étude géologique et hydrogéologique du Sud-Est de la Côte d'lvoire. Bassin versant de la Mé. Thesis, University of Grenoble 1, Institut Dolomieu, France, 218 p.

Soro, N. (2002). Hydrochimie et géochimie isotopique des eaux souterraines du degré carré de Grand-Lahou et ses environs (sud-ouest de la Côte d'Ivoire). Implication hydrologique et hydrogéologique. PhD Thesis, University of Abidjan, 272 p.

Soro, N, Savané, I, Ouattara, A et Fofana, S. (2001). Approche géostatistique de la variabilité spatiale des écoulements souterrains dans les aquifères du SudOuest de la Côte d'Ivoire. Rev. Bioterre 2 (1) : 85100.

Srivastav, S.K., Lubczynski, M.W, Biyani, A.K (2007). Upscalling of transmissivity, derived from specific capacity : a hydrogeomorphological approach applied to the Doon Valley aquifer system in India. Hydrogeol. J. $15: 1251-1264$.

Tagini, B. (1971). Esquisse structurale de la Côte-d'Ivoire. Essai de géotectonique régionale. $\mathrm{PhD}$ Thesis, University of Lausanne (Suisse), $302 \mathrm{p}$.

Theis, C.V (1935). The relation between the lowering of the piezometric surface and the rate and duration of discharge of the well using ground-water storage. Trans. Am. Geophys. Union 16 : 519-524.

Youan Ta, M. (2008). Contribution de la télédétection et des systèmes d'informations géographiques à la prospection hydrogéologique du socle précambrien d'Afrique de l'ouest: Cas de la région de Bondoukou Nord Est de la Côte d'Ivoire. PhD Thesis, University of Abidjan (Côte d'Ivoire), 236 p.

Youan Ta, M., Lasm, T., Jourda, J.P, Kouamé, K.F et Razack, M. (2008). Cartographie structurale par imagerie satellitaire ETM+ de Landsat-7 et analyse des réseaux de fractures du socle précambrien de la région de Bondoukou (nord-est de la Côte d'Ivoire). Télédét. 2 : 34-42.

Yacé, I. (2002). Initiation à la géologie. L'exemple de la Côte d'Ivoire et de l'Afrique de l'Ouest. Edition CEDA, $183 \mathrm{p}$. 